\title{
The Mediation Effect of Customer Satisfaction in Relationship between Product Quality and Service Quality towards Customer Loyalty In Fuzee Sushi
}

\author{
Charly Hongdiyanto ${ }^{\mathrm{a}^{*}}$, Kevin Liemena ${ }^{\mathrm{b}}$ \\ aniversitas Ciputra Surabaya \\ bUniversitas Ciputra Surabaya \\ email: charly@ciputra.ac.id
}

\begin{abstract}
Food and beverage industry in Indonesia has been growing constantly every year and also contributed to manufacture and economy growth in both current and the next following years. The important role of food and beverage industry is transparent through the consistent contribution and significant impact toward Gross Domestic Product and food and beverage startup businesses has been experiencing growth every year due to the growth of population in Indonesia. This study was made to know the effect of product quality and service quality towards customer loyalty of Fuzee Sushi. There is also customer satisfaction as a mediator between product quality and service quality to customer loyalty. This research aims on Fuzee Sushi' customers that has bought the product more than once. An online questionnaire was distributed to the entire sample and used five points Likert scale as a measurement method. The data are analyzed using Partial Least Square. The result of this research showed that product quality has positive relationship toward customer loyalty directly however, service quality does not have positive impact directly toward customer loyalty. Product quality and service quality mediated by customer satisfaction has positive impact towards customer loyalty. The findings purpose is to understand more about product quality, service quality, customer satisfaction, and customer loyalty relationship in start-up food and beverage business in Indonesia.
\end{abstract}

Keywords: product quality, service quality, customer satisfaction, customer loyalty

\section{Introduction}

Food and beverage industry in Indonesia has been growing constantly in every year and also contributed to manufacture and economy growth in both current and next following years. The important role of food and beverage industry is transparent through the consistent contribution and significant impact toward Gross Domestic Product and the growth of population.

The opportunity that has been offered from food and beverage industry has led the researcher to create a business named Fuzee Sushi established in 2015. Fuzee Sushi include in F\&B which offer the product of a Sushi Roll however, the unique characteristic of this product is to be eaten similar to kebab without being cut as original sushi should have been. The first name of the business is Wildest Taste however, due to the concept of product does not match the business name, it was decided to change into Fuzee Sushi which interpret the product as a sushi and each different flavors are able to mix according to customer' preferences.

The growth of food and beverage industry created a strict competitive impact toward the industry. Competition in culinary industry including Japanese cuisine affecting Fuzee Sushi in terms of sales. 


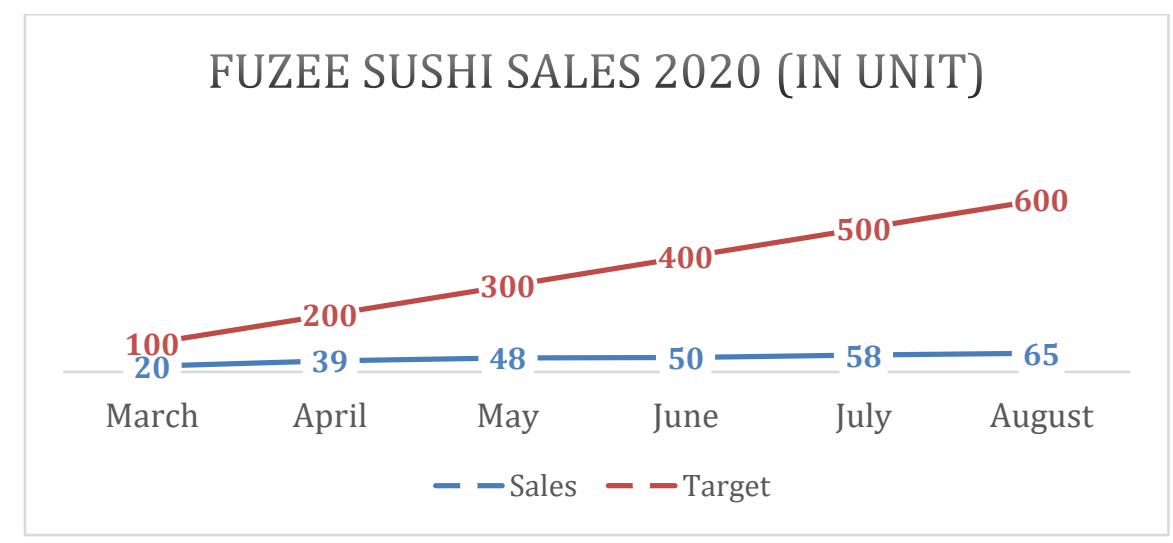

Figure 1. Fuzee Sushi Sales in 2020

Figure 1 shows the decreases of sales begin from March to August which implies the sales are decreasing and does not meet the sales target in 2020. From the data provided it could lead to negative impact to the company if the decrease of sales are left out without finding a solutions to this problem. Due to this problem, the researcher conducted a preliminary survey to 20 respondents who already tried Fuzee Sushi product. Figure 2 shows the result from preliminary survey to 20 respondents, there are $75 \%$ customer (15 respondents) who answered not satsify to the product provided. While the rest of $25 \%$ (5 respondents) answered they satisfy with the product provided. The number of customers who are not satisfy are higher than the customer who are satisfy with the product.

\section{CUSTOMER SATISFACTION}

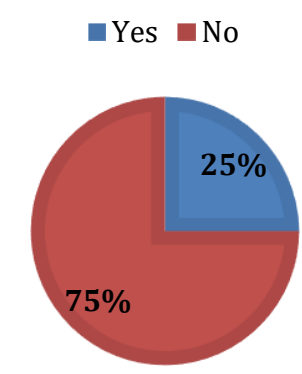

Figure 2. Customer Satisfaction in Fuzee Sushi

The researcher then divide the aspects of unsatisfactory into five categories which are the product quality, service quality, price, promotion and other for the customers that are not satisfy with the product in order to know the details regarding their complaints. Further research is necessary to know which negatively affecting customer's satisfaction the most and those are the variables needed to be improved. There are 15 Out of 20 total customers who are not satisfy with the product and the highest causes of dissatisfaction comes from the product quality itself which is $41 \%$ ( 6 customers), followed by the second caused by the service quality which is $27 \%$ ( 4 customers), both price and packaging have the same amount of percentage which is $13 \%$ (2 customers) and the lowest cause is promotion with the percentage of $6 \%$ ( 1 customer). According to Figure 3, can be concluded that product quality and service quality are the highest cause of customer unsatisfactory that is needed to be addressed in order to increase customer 
satisfaction. The researcher perceive that product quality and service quality is a primary influence on the decrease of the sales in Fuzee Sushi.

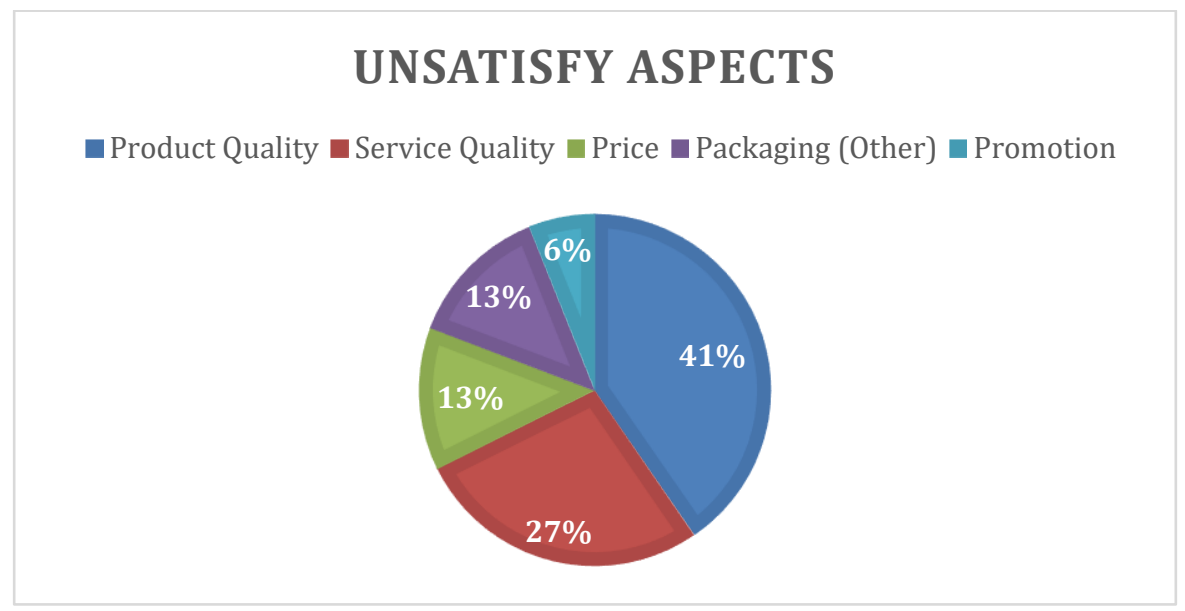

Figure 3. Unsitisfy Aspects

Product quality and service quality affecting customer loyalty mediated by customer satisfaction. Fernandes \& Solimun (2017) mentioned that not all variables can directly affect customer loyalty however, they must going through customer satisfaction and customer will be loyal when the level of satisfaction is resolved. In order to increase the sales, customer satisfaction must be fulfilled to gain customer loyalty therefore, a succeeded company is a company that has achieved customer's loyalty which is the willingness from a customer to purchase or buy similar product and at the same time manage to retain a profitable relationship with a company, continuously buying the product also suggesting the same product to other people whether it is friend or family. The important variables needed to be improved with the objective to satisfy customer are product quality and service quality, customer satisfaction are both significantly and positively affecting customer loyalty (Carranza, Díaz, Consuegra 2018). Based on this findings, the researcher is eager to conduct a research with a title "The Mediation Effect of Customer Satisfaction in Relationship between Product Quality and Service Quality towards Customer Loyalty in Fuzee Sushi”.

\section{Theoretical Foundation}

\section{Product Quality}

According to Kotler \& Armstrong (2018) product quality is the characteristics of a product or service that bear on its ability to satisfy customer needs. Quality affects product performance and it is closely related to customer value and customer satisfaction. This statement is supported by Nuridin (2018) which mentioned product quality indirectly affecting customer loyalty through customer satisfaction positively and significantly. There are some indicators regarding product quality which stated by Kotler \& Keller (2008) in Nuridin (2018) and those dimensions are Form, features, performance, accuracy / conformance, durability, reliability, reparability, style, and design. Not all the indicators or variables regarding the product quality listed above will be used in this research due to the adjustment of this research and the type of product in food and beverage industry, the indicators that will be used in this research are: 
1. Form, the product is clearly distinguished from others based on shape, size, or physical structure of the product.

2. Performance, functional aspect and the main strength of the product

3. Accuracy/Conformance, the precision of which quality of the product has the standard quality.

4. Design, overall product features which will affect the appearance and function of the product to customer's demand.

\section{Service Quality}

According to Iacobucci, Shannon, \& Grigoriou (2015) if the service given in reality is better than customer's expectations, then the service is considered high quality. If the service provided is fit into customer's expectations, the service is considered satisfactory. However, if the service is below or failed to meet customer's expectations, then the service can be considered as a low quality. Service quality is a measurement to service performance delivered by a company with an objective to matches customer's expectations, they also added service quality is the gap between customer's expectations of the service and their perceptions of the actual service which is provided by the company. Fernandes \& Solimun (2017) gave the idea according from their research that service quality is based on customer point of view toward the service which namely customer's perception on the received or perceived service and also the actual expected or desired service. There are some indicators regarding product quality which stated by Kotler \& Keller (2008) in Nuridin (2018) and those dimensions are Form, features, performance, accuracy/conformance, durability, reliability, reparability, style, and design. Not all the indicators or variables regarding the product quality listed above will be used in this research due to the adjustment of this research and the type of product in food and beverage industry, the indicators that will be used in this research are:

1. Form, the product is clearly distinguished from others based on shape, size, or physical structure of the product.

2. Performance, functional aspect and the main strength of the product

3. Accuracy/Conformance, the precision of which quality of the product has the standard quality.

4. Design, overall product features which will affect the appearance and function of the product to customer's demand.

\section{Customer Satisfaction}

According to Kotler \& Keller (2016) satisfaction is a person's feelings of pleasure or disappointment that result from comparing a product or service perceived performance to expectations. If the performance or experience falls short of expectations, the customer is dissatisfied, if it matches the expectations, the customer will satisfied and if it exceeds customer's expectation then the customer will highly satisfied or delighted. Satisfaction is a key determinant in customer's decision of whether they continue or discontinue their association with the product or service (Tandon, Kiran, Sah, 2017). According Nuridin (2018), there are three indicators of customer satisfaction which are: 
176 Hongdiyato and Liemena (2021) The Mediation Effect of Customer Satisfaction in Relationship between Product Quality and Service Quality towards Customer Loyalty in Fuzee Sushi

1. Conformity, the product performance expected by customers and perceived by customers includes products, services, and supporting facilities which are obtained in accordance or exceeded with the expected.

2. Revisit, the willingness of customers to visit again or make a repurchase of certain and related products or services.

3. Recommendation, when customer is willing to recommend the product that has been tried to family or friends.

\section{Customer Loyalty}

Grewal \& Levy (2016:31) stated that by providing or delivering outstanding customer service and develops value based strategies with the goal to retain loyal customers, customer excellence can be achieved. Loyalty is a psychological condition related to attitudes toward a product according (Adji Achmad Rinaldo, Solimun, 2017). In business, customer loyalty plays an important role in a company as to maintaining customers. Customer loyalty is whether they like the product or not and decide whether the customer will buy the product again or not. If the a company gain customer's loyalty then the customer will likely to purchase the product again in the future as long the company achieve the loyalty from customers. There are three indicators of customer loyalty according to Nuridin (2018) which are:

1. Purchase regularly, customers who had a transaction is a company is satisfied and tend to create a close relationship resulting in repeat purchases.

2. Purchase inter-line products and services, customers also consider to buy another items for their product namely accessories, basically customers buying another type of product and not just one.

3. Showing immunity towards other competitors, customer tend to not use other products from another company due to high compatibility with their main products.

\section{Research Methodology}

The method of research use in this study is quantitative research. According to Creswell (2014), quantitative research is a method in testing objective theories by analyzing relationship between variables. Variable are then measured, processed, and analyzed through the statistical procedure.

Population of this research are the customer of Fuzee Sushi or those who experienced the product of Fuzee Sushi and tries the product more than once which is 89 respondents. Sampling is the process of selecting a statistically representative sample of individuals from the population of interest (Majid et al, 2018). The researcher must determine the sample of this research by using the saturation sample in non-probability sampling, that is the sample that include all of the population as the sample of this research which is 89 respondents due to the population is reachable to the researcher.

According to Bolarinwa (2017), questionnaire is a tool for collecting and recording information by delivering predetermined set of questions to the respondents. In this research, the questionnaire questions are related to product quality, service quality, customer satisfaction, and customer loyalty. The researcher will use the Likert scale in the online questionnaire. Likert chart indicates the extend in which the respondent agreed or disagreed with each series of 
statements related to the focus of attitude (Willits et al, 2016). Respondents able to score each statement from (1) strongly disagree, (2) disagree, (3) neutral, (4) agree, (5) strongly agree. Data Analysis Methods

In measuring the variables, the researcher will use the Likert scale in the online questionnaire. Likert chart indicates the extend in which the respondent agreed or disagreed with each series of statements related to the focus of attitude (Willits et al, 2016). Respondents able to score each statement from (1) strongly disagree, (2) disagree, (3) neutral, (4) agree, (5) strongly agree. According to Garson (2016), Partial Least Square is a technique that is used in prediction or exploratory modeling, in which it can relate from set of independent variables towards multiple dependent variables. In this research, the Partial Least Square equation is:

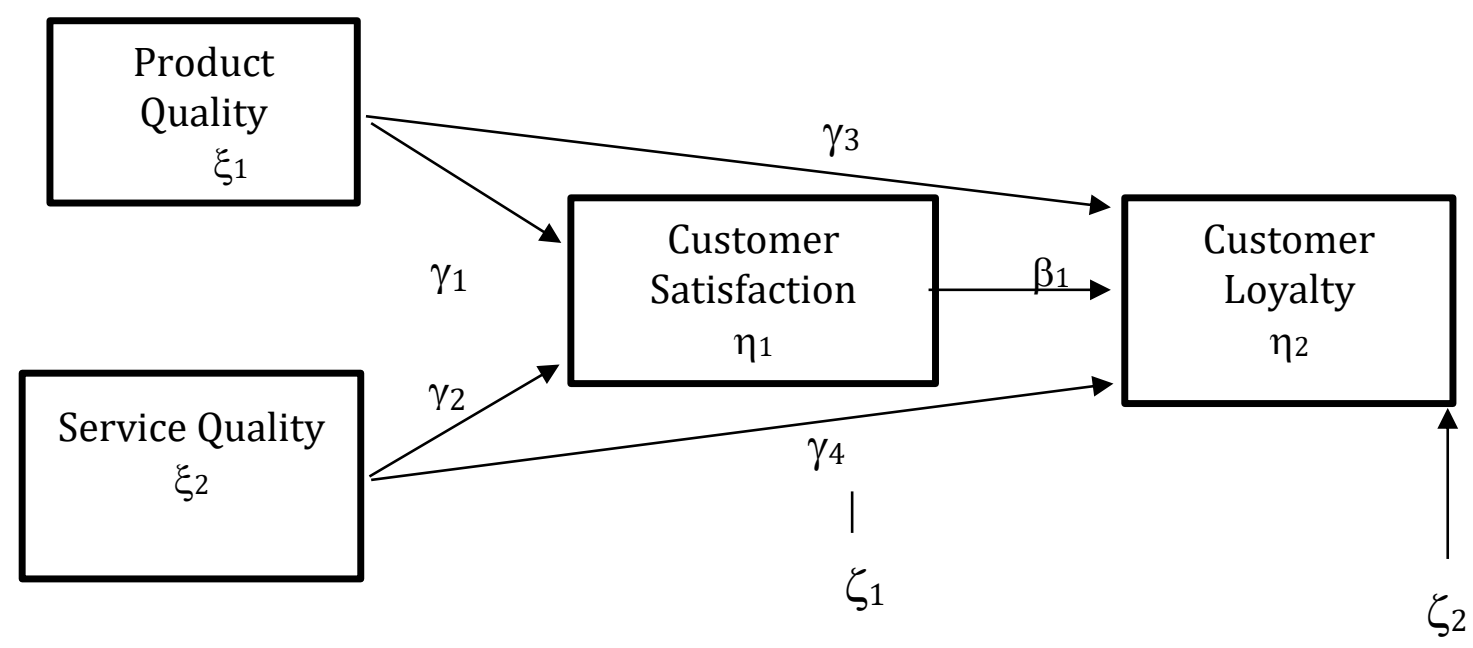

Figure 4. Partial Least Square Equation

$$
\begin{gathered}
\eta_{1}=\gamma_{1} \cdot \xi_{1}+\gamma_{2} \cdot \xi_{2}+\zeta_{1} \\
\eta_{2}=\gamma_{3} \cdot \xi_{1}+\gamma_{4} \cdot \xi_{2}+\beta_{1} \cdot \eta_{2}+\eta_{1} \\
\gamma_{1}=\text { Effect of } \xi_{1} \text { to } \eta_{1} \quad \gamma_{3}=\text { Effect of } \xi_{1} \text { to } \eta_{2} \\
\gamma_{2}=\text { Effect of } \xi_{3} \text { to } \eta_{1} \quad \gamma_{4}=\text { Effect of } \xi_{2} \text { to } \eta_{2} \\
\beta=\text { Effect of } \eta_{1} \text { to } \eta_{2} \\
\begin{array}{r}
\xi_{2} \text { Independent Variable } \\
\eta_{1}=\text { Intervening Variable }
\end{array} \quad \eta_{2}=\text { Dependent Variable } \\
\zeta_{1}, \zeta_{2}=\text { (Other Variable) }
\end{gathered}
$$

\section{Research Discussion and Findings}

\section{Research Object}

Research object used in this research is Fuzee Sushi's customer. In order to get the sample numbers, the researcher used saturation sampling method where the amount of population is the sample as well. 89 people were asked to fill in the questionnaire about product quality, service quality, and customer satisfaction towards customer loyalty. Most of the respondents are $21-28$ years old with $83.15 \%$ of total percentage whereas respondents with age $15-20$ years old are $14.60 \%, 29-40$ years old are $0 \%$, and $41+$ years old are $2.25 \%$. Meaning 
178 Hongdiyato and Liemena (2021) The Mediation Effect of Customer Satisfaction in Relationship between Product Quality and Service Quality towards Customer Loyalty in Fuzee Sushi

that most of the customer that consumed the product more than once in Fuzee Sushi are in 21 to 28 years old.

Table 1. Respondents' Age

\begin{tabular}{lcc}
\hline \multicolumn{1}{c}{ Age } & Total & Percentage \\
\hline 15-20 years old & 13 & $14.60 \%$ \\
21-28 years old & 74 & $83.15 \%$ \\
29-40 years old & 0 & $0 \%$ \\
41+ years old & 2 & $2.25 \%$ \\
Total & $\mathbf{8 9}$ & $\mathbf{1 0 0 \%}$ \\
\hline
\end{tabular}

\section{Descriptive Respondents' Answer Product Quality}

The highest perception comes from the X1.2 which has the average of 4.247 , while the lowest perception comes from the X1.4 which has 3.854 average result. X1.4 of this variable gave the highest standard deviation (0.966), which means this question has more variety in distribution. The lowest standard deviation is from X1.2 which is 0.797 . It means that question 2 's answers are mostly homogeneous or majorly focused in one point of answer.

\section{Descriptive Respondents' Answer Service Quality}

The highest average result comes from X2.2 with 4.337 mean result. The lowest average result comes from X2.3 and X2.5 both with 4.146 mean result. On the other hand, X2.3 gave the highest result of standard deviation which is 0.868 . It means that the respondents' answer in question 3 are more distributed than in other questions. Meanwhile, for the lowest standard deviation is from X2.4 which is 0.801 . It means that question 4's answers are mostly homogeneous or focused in one answer. This shows that most respondents agree to the service quality given are good.

\section{Descriptive Respondents' Answer Customer Satisfaction}

Question 2 has the highest standard deviation which is 0.935 . It means that the respondents' answer on question 2 is well distributed if compared to the other questions. On the other hand, question 1 has the lowest standard deviation, which is 0.792 . It means that the respondents' answers are homogeneous or focused in one point. This shows that most of the respondents are mostly satisfy. For the average mean result, question 2 has the highest mean result which is 4.191 , question 1 and 3 has the lowest mean result which is 4.157 .

\section{Descriptive Respondents' Answer Customer Loyalty}

The highest mean result is from question 1 which is 3.876, and the lowest mean result is from question 3 which is 3.843 . The distribution of answers within each question can be seen from the standard deviation result. The highest result came from question 2, which is 1.023 and the lowest result came from question 3 , which is 0.886 . The lowest result means that the respondents' answers are homogeneous or majorly focused in one point of answer.

\section{Validity and Reliability Test}

Validity and Reliability test will be used to test the questionnaire results. The test will be tested to all variables in this study. According to Garson (2016), a variable is categorized as valid when the outer loading value is above 0.7; Average Variance Extracted (AVE) value is 
above 0.5 ; and it has the highest scores in the cross-loading test. For the convergent validity test, all the variables could pass above the value of 0.7 by looking at the outer loading value. The AVE result needs to be above 0.5 , and all variables could also exceed 0.5 . In the discriminant validity test, by looking at the scores of cross loading value, each variable needs to perform the highest score in the destination construct. All variables could perform the highest score compared to other variables in each section. As all the variables can pass the convergent, discriminant, and Average Variance Extracted (AVE) tests, it is concluded that all variables in this study are valid. To test the reliability, a variable must pass 0.6 for both Cronbach's Alpha and composite reliability test (Garson, 2016). From the result of two tests, all the variables could perform more than 0.6 score for Cronbach's Alpha. Meanwhile, for the composite reliability test, all variables could also perform more than 0.6 score Thus, it is concluded that all of the variables are reliable.

Table 2. PLS Equation of $Y$

\begin{tabular}{lcc}
\hline & Original Sample (0) & P Values \\
\hline Product Quality & 0.417 & 0.000 \\
Service Quality & 0.468 & 0.000 \\
\hline
\end{tabular}

Table 2 shows the result of Y PLS equation. This table explains about the effect of variable of product quality $\left(\mathrm{X}_{1}\right)$ and service quality $\left(\mathrm{X}_{2}\right)$ towards variable of customer satisfaction (Y). The p-values of both variables is below 0.05 . The original sample result of product quality is 0.417 , which means product quality is directly giving positive influence towards customer satisfaction.

Table 3 shows the result of Z PLS equation. It defines the effect of the variables product quality $\left(\mathrm{X}_{1}\right)$, service quality $\left(\mathrm{X}_{2}\right)$, and customer satisfaction $(\mathrm{Y})$ towards customer loyalty $(\mathrm{Z})$. The $\mathrm{p}$ values for product quality and customer satisfaction is below 0.05 , meanwhile the $\mathrm{p}$ values for service quality is above 0.05 and original sample is -0.095 , it means that the variable of service quality has negative relationship towards customer loyalty.

Table 3. PLS Euation of $\mathrm{X}$

\begin{tabular}{lcc}
\hline & Original Sample (0) & P Values \\
\hline Product Quality & 0.494 & 0.002 \\
Service Quality & -0.095 & 0.480 \\
Customer Satisfaction & 0.370 & 0.015 \\
\hline
\end{tabular}

Table 4 shows the total influence of direct and indirect influence from two dependent variables which are product quality and service quality. The direct influence of product quality towards customer loyalty is 0.494 , meanwhile the direct influence of service quality towards customer loyalty is -0.095 . It means that the indirect value that is 0.173 in service quality is bigger than direct influence value which is -0.095 . As for product quality, the direct influence is bigger than indirect influence. It can be seen from the direct value at 0.494 , and the indirect value at 0.155 . 
180 Hongdiyato and Liemena (2021) The Mediation Effect of Customer Satisfaction in Relationship between Product Quality and Service Quality towards Customer Loyalty in Fuzee Sushi

Table 4. Path Coefficient between Variables

\begin{tabular}{rccc}
\hline No & Variable & $\begin{array}{c}\text { Direct } \\
\text { Influence }\end{array}$ & $\begin{array}{c}\text { Indirect } \\
\text { Influence }\end{array}$ \\
\hline 1 & Product Quality & 0.494 & 0.155 \\
2 & Service Quality & -0.095 & 0.173 \\
\hline
\end{tabular}

The PLS model in this study will be as follows:

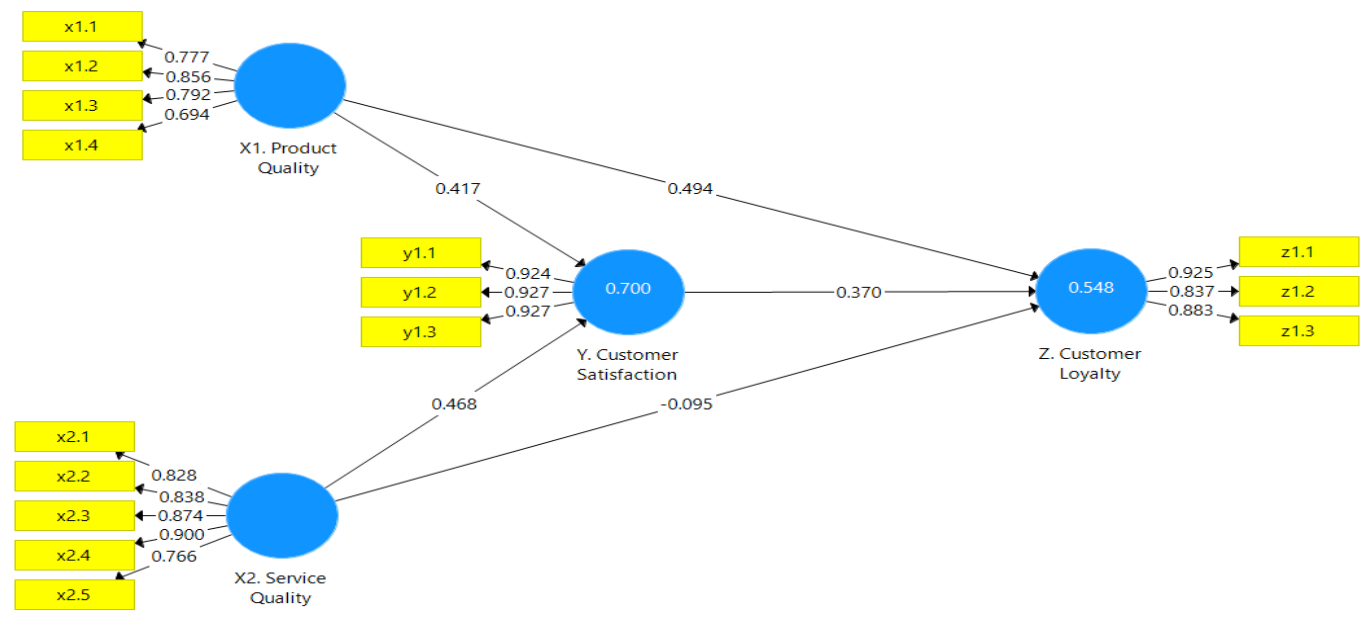

Figure 5. Partial Least Square Model

Table 5. t-Statistic and $P$ Values

\begin{tabular}{lccc}
\hline & $\begin{array}{c}\text { Original } \\
\text { Sample (O) }\end{array}$ & $\begin{array}{c}\mathbf{t} \\
\text { Statistic }\end{array}$ & $\begin{array}{c}\text { P } \\
\text { Values }\end{array}$ \\
\cline { 2 - 4 } & 0.494 & 3.161 & 0.002 \\
Product Quality & -0.095 & 0.707 & 0.480 \\
$\begin{array}{l}\text { Service Quality } \\
\text { Product Quality } \\
\text { (Mediated) }\end{array}$ & 0.155 & 2.182 & 0.030 \\
$\begin{array}{l}\text { Service Quality } \\
\text { (Mediated) }\end{array}$ & 0.173 & 2.177 & 0.030 \\
$\begin{array}{l}\text { Customer } \\
\text { Satisfaction }\end{array}$ & 0.370 & 2.445 & 0.015 \\
\hline
\end{tabular}

In Table 5 only four variables pass the t-value test and p-value test. The t-value test must be above 1.96 and p-value test must be under 0.05. Based on the table, it can be seen that service quality (direct relationship) has t-value of 0.707 , which means there is no significant effect from service quality towards customer loyalty. However, the direct relationship of product quality with t-value of 3.161 is showing significant effect as the t-value above 1.96. For the mediated path through customer satisfaction shows that there is a significantt effect between product quality (mediated) with t-value of 2.182 and service quality (mediated) with t-value of 2.177 as the $\mathrm{t}$-value are above 1.96. The mediator which is customer satisfaction with $\mathrm{t}$-value of 2.445 have significant effect towards customer loyalty. It can be concluded that product quality (direct relationship), product quality (mediated relationship), service quality (mediated relationship), 
and customer satisfaction have significant effects towards customer loyalty. Meanwhile, service quality (direct relationship) have no significant effect towards customer loyalty.

\section{Conclusion and Suggestion}

Based on the result of the discussion, it can be concluded that:

1. Product quality has significant influence towards customer loyalty of Fuzee Sushi.

2. Service quality does not have significant influence towards the customer loyalty of Fuzee Sushi.

3. Product quality mediated by customer satisfaction has significant influence towards customer loyalty of Fuzee Sushi.

4. Service quality mediated by customer satisfaction has significant influence towards customer loyalty of Fuzee Sushi.

5. Customer satisfaction has significant influence towards customer loyalty of Fuzee Sushi

Suggestions that can be made after achieving the result of study as follows:

For start-up businesses:

To understand the effect of product quality and service quality with or without customer satisfaction towards customer loyalty and as a knowledge to support their start-up businesses.

For the researcher:

To understand the effect of product quality and service quality with or without customer satisfaction towards customer loyalty and to gain knowledge to support future business.

For the readers:

To have knowledge and to understand the effect of product quality and service quality with or without customer satisfaction towards customer loyalty and to make this research as a future reference.

\section{References}

Bolarinwa, O. A. (2017). Principles and Methods of Validity and Reliability Testing of Questionnaires Used in Social and Health Science Researches. Nigerian postgraduate Medical Journal, 195-201.

Carranza, R., Díaz, E., \& Consuegra, D. M. (2018). The influence of quality on satisfaction and customer loyalty with an importance-performance map analysis: Exploring the mediating role of trust. Journal of Hospitality and Tourism Technology, Vol. 9, 380-396.

Creswell, J. W. (2014). Research Design: Qualitative, Quantitative and Mixed Methods Approaches. United States of America: SAGE Publications.

Dror, R., Baumer, G., Shlomov, S., \& Reichart, R. (2018). Proceedings of the 56th Annual Meeting of the Association for Computational Linguistics (Long Papers). Association for Computational Linguistics, 1383-1392.

Endhy, R. P. (2017). The Role of Entrepreneeurial Passion and Entrepreneurial Creativity Including Mediated by Self-Effifacy in Developing The Entrepreneurial Intention in Ciputra University. Surabaya: Thesis. 
Fernandes, A. A. (2017). The Mediation Effect of Customer Satisfaction on the Relationship between Service Quality, Service Orientation, and Marketing Mix Strategy to Customer Loyalty. Journal of Management Development.

Garson, G. D. (2016). Validity \& Reliability. Asheboro: Statistical Associates Publishing.

Gogtay, N., \& Thatte, U. (2017). Principles of Correlation Analysis. Journal of the Association of Physicians of India, 65, 78-81.

Grewal, D., \& Levy, M. (2016). Marketing 5th Edition. New York: McGraw-Hill Education.

Handoko, L. P. (2016). The Effect of Product Quality and Delivery Service on Online Customer Satisfaction in Zalora Indonesia. 1189-1199.

Hutabarat, J. P., Bross, N., \& Utomo, K. W. (2018). The Effect of Service Quality and Brand Image towards Customer Loyalty with Customer Satisfaction as Intervening Variable. International Journal of Novel Research in Marketing Management and Economics Vol.5, 87-98.

Iacobucci, D., Shannon, R., \& Grigoriou, N. (2015). Marketing Management in Asia. Singapore: Cengage Leaning Asia Pte Ltd.

Katadata. (2019, 01 24). 2018, Jumlah Penduduk Indonesia Mencapai 265 Juta Jiwa. Diambil kembali dari databoks.katadata: https://databoks.katadata.co.id/datapublish/2018/05/18/2018-jumlah-pendudukindonesia-mencapai-265-juta-jiwa

Kemenperin. (2019, 01 24). Industri Makanan dan Minuman Masih Jadi Andalan. Diambil kembali dari Kementrian Perindustrian Republik Indonesia: http://www.kemenperin.go.id/artikel/18465/Industri-Makanan-dan-Minuman-MasihJadi-Andalan

Kotler, P., \& Armstrong, G. (2016). Principles of Marketing 16th Edition. England: Pearson Education Limited.

Kotler, P., \& Armstrong, G. (2018). Principles of Marketing 17th Edition. United Kingdom: Pearson Education Limited.

Kotler, P., \& Keller, K. L. (2016). Marketing Management Global Edition. England: Pearson Education Limited.

Majid, U. (2018). Research Fundamentals: Study Design, Population, and Sample Size. Undergraduate Research In Natural and Clinical Science and Technology (URNCST) Journal Vol.2, 1-7.

Mohajan, H. (2017). Two Criteria for Good Measurements in Research: Validity and Reliability. 1-31.

Nuridin. (2018). Effect of Service Quality of Products to Customers Loyalty with Customer Satisfaction as Intervening Variable in PT. Nano Coating Indonesia. International Journal of Business and Applied Social Science (IJBASS), 19-31.

Taherdoost, H. (2016). Sampling Methods in Research Methodology; How to Choose a Sampling Technique for Research . International Journal of Academic Research in Management (IJARM), 18-27.

Tandon, U., Kiran, R., \& Sah, A. (2017). Analyzing customer satisfaction: users perspective towards online shopping. Nankai Business Review International, Vol. 8, 266-288.

Willits, E. A. (2016). Another Look at Likert Scale. Journal of Rural Social Sciences, 31(3), 126-139. 